\begin{tabular}{|l|} 
HC \\
108 \\
S2W3X \\
NMAH \\
\\
\end{tabular} 






\section{THE WESTWARD MOVEMENT}
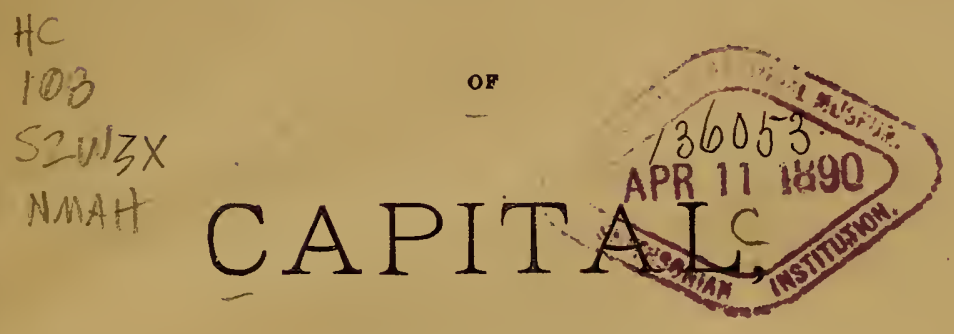

And the Facilities which

\section{ST. LOUIS AND MISSOURI}

OFFER FOR

ITS INVESTMENT.

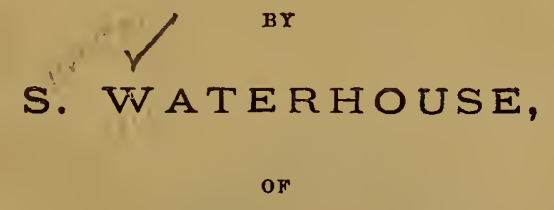

WASIIINGTON UNIVERSITY.

Fourth Edition 50,000 Copies, - Total Issue 80,000 Copies. 


\title{
PUBLISHED
}

\author{
BY THE
}

\section{MERCHANTS' EXCHANGE \\ OF}

\section{SAINT LOUIS.}

\author{
FEBRUARY, 1890.
}




\section{The Westward Migration of Commerce and Manufactures, AND the Advantages Which Invite them to A Permanent Settlement in Missouri.}

The grandeur of ancient Rome was peerless. The treasures of a conquered world enriched its mistress. Embellished with fountains of curious art and the captive masterpieces of Grecian sculpture, adorned with pillar, arch, and coliseum, and splendid with massive marble palaces and temples, the Roman capital was the fitly majestic seat of universal empire. Even the ruins of its olden magnificence are to-day most impressive monuments of human greatness. The naval supremacy of Rome opened every harbor to its commerce. Trade followed conquest. The products of every land supplied the wants and luxuries of the imperial city. Rome was then the commercial metropolis of the world.

Afar off in the northern ocean, there lay an island inhabited by half-clad savages. Its partial subjugation by Cæsar had made it imperfectly known at Rome. The obscure isle was deemed too insignificant to excite even a Roman ambition to complete conquest. Had it then been foretold that in future centuries a humble hamlet in the far-distant and scarcely known island would surpass the commercial greatness of Rome, the proud metropolis would have regarded the prophecy as too wild a fiction for even the imagination of a poet to conceive. But the lapse of ages has fulfilled this improbable prediction. Trade has commonly followed naval ascendency. Victorious fleets are safe convoys for merchantmen. In extent of commercial empire, the modern "Mistress of the Seas" far surpasses the ancient "Mistress of the World." The rude village of the days of Cæsar has developed into a vast metropolis whose world-wide commerce dwarfs that of imperial Rome into comparative insignificance. But London will not always retain its mercantile supremacy. The center of trade is not permanently stationary. In its migration from Rome to London, it visited various lands. Its westward journey is not yet ended. In remote ages, victory controlled trade; but the arts of modern civilization have changed the conditions of national growth. Never again will a single city wield universal sway. In recent times, public education and the application of invention to the industries of peace and the enginery of war have more nearly equalized 
the powers of the great nations. Henceforth a superiority in natural advantages and in facilities for exchange will determine what city shall be the capital of commerce.

In this competition, New York will soon win an easy victory. The wealth of the United States is alreacly greater than that of any other country on earth. But as yet our resources have been very imperfectly developed. In the coming time, a dense population of high intelligence and tireless activity will occupy our national domain. Then the almost illimitable products of soil, mine, and industrial art will constitute a wealth whose vastness will defy rivalry and bewilder computation. Never in the annals of time has any metropolis equaled New York in the extent and richness of its commercial tributaries. The nations subject to Rome were mostly unlettered races who were held together by no bonds of a common blood, speech, or patriotism. They paid a reluctant and insincere homage to their imperial mistress. Both their wants and their wealth-producing capacities were limited. But the people of the United States are the educated citizens of a free government. They are substantially homogeneous in ancestry, language, and interests. They inhabit a country of vast dimensions and inexhaustible resources. A high civilization develops an almost infinite diversity of industries to supply its innumerable wants. Under the inspiration of free institutions, with their cultivated intelligence, inventive genius, and restless energy, Americans will create a wealth whose magnitude will startle political economists. A large part of this enormous opulence will seek foreign exchange through our great metropolis. Long before the expiration of another century, New York will have become the financial center of the world.

But industrial movements, somewhat resembling the grander migrations of commercial empire, are now going on in the United States. The limited manufactures of the first American settlements were necessarily restricted to the Atlantic colonies. At that time, only a few daring explorers had ventured beyond the Alleghanies. Even in the earlier days of our Republic, the hardy pioneers who had settled in the Mississippi valley were still dependent upon Europe and the Atlantic states for all of their commercial supplies. They had neither the wealth to establish manufactories nor the patronage to sustain them. But latterly great changes hare taken place in the industrial conditions of the United States. Three-score millions of people now occupy our vast domain. The center of population, already far west of the Alleghanies, is rapidly approaching the Mississippi river. Between the crests of the Rocky and Sierra Nevada mountains there are hundreds of towns busy with all the activities of modern life; and on the Pacific coast there are many cities which the profits of local industry and oriental commerce 
are making great and opulent. Invention has invested the continent with a nervous system which thrills with the messages of universal intelligence. Lines of rapid transit, traversing every section of our Union and binding all its members in an alliance of common interests, serve alike the needs of commerce, travel, and defense. Machines of marvelous ingenuity facilitate the labors of every industry. Indeed, mechanic art has effectively promoted the assimilation and unity of the American people. The enormous growth of population and wealth has led to the erection of manufactories in every part of our land. The east no longer retains its relative ascendency. Many furuaces, foundries, and iron-works have been established in the south and west. The freight on bulky products has been saved by transferring the machine-shops to the center of consumption. Transportation from the east adds from ten to twenty per cent. to the cost of cheap and, heavy goods. On such articles, this freight is almost equivalent to a prohibitory tariff in favor of western manufacturers. Availing themselves of this discrimination and perceiving that the profits of production are larger than those of sale, sagacious capitalists are building factories in every section of the Mississippi valley. The limits of this article will not permit an extended citation of industrial statistics. But fortunately no long array of figures is necessary. A few facts gathered from wholesale dealers will prove the westward tendency of manufacturing iudustries. All of these statements apply to cheap and bulky products. The coarser fabrics are now largely made in the west, but the finer grades of light and costly goods are still brought from the east. Twcnty-five years ago nearly all of the clomestic merchandise consumed in the west was manufactured east of the Alleghanies. Now from 60 to 90 per cent. of weighty and low-priced wares are made in the Mississippi valley. In special lines, the increase of western manufactures has varied from 15 to 50 per cent. in the last ten years. It is probable that from threefifths to three-quarters of the heavier commodities which now supply the markets of our central states are made west of the Alleghanies.

These significant facts show that the westward migration of manufactories is a general and rapid movement. This transition, obeying economic laws and inc:upable of arrest, will compel a readjustment of eastern industries. Every section of our country now exhibits an unmistakable disposition to supply its own wants. Every region in which the cost of transportation from other localities permits a profit is establishing its own manufactories. This universal and strongly marked tendency towards industrial independence is a distinctive feature of our material development. Capital, delicately sensitive to every economic change ancl actively adventurous in quest of protit, always seeks the nost favorable places for investment. Latterly millions of easteru money have been expended in the 
establishment of furnaces, factories, and workshops in our southern states. Doubtless the westward flow of uorthern funds will continue.

Mlssouri invites manufacturers and capitalists who are exploring the west for opportunities of proftable investment to a consideration of its advantages. Missouri is richly blessed with the bounties of nature. Situated midway between the Arctic and Torrid zones, it enjoys the golden mean of temperature. Its climate is equally exempt from the sultry heat of the south and the intense cold of the north. Its airs are pure and its waters healthful. With the exception of the mountainous portions of the state, the fertility of the soil rewards the labors of the husbandman with plenteous harvests. The beautiful valleys and undulating uplands present picturesque sites for rural homes. The agreeable inequalities of surface, not sufficiently abrupt to embarrass tillage, diversify the scenery and offer facilities for drainage which the level prairie can never afford. All the vegetables, fruits, fibers, grains, and trees which the temperate zone produces grow luxuriantly in the soil of Missouri. A vast state welcomes the husbandman of every land to a participation in its proffered advantages. Missouri comprises more than $44,000,000$ acres. A territory so imperial in extent can supply myriads of new settlers with comfortable homes and profitable occupation.

But Missouri is rich not only in the productions of its soil, but also in the resources of its mines. In its banks, the hand of partial nature has stored uncounted treasures. Its vaults are full of mineral wealth. Doubtless there is a greater opulence of precious metals in the rugged wastes of the Rocky and Nevada ranges, but no state whose soil is fruitful equals Missouri in the variety and abundance of its minerals. Saline, sulphurous, and chalybeate springs, asphalt, emery, plumbago, kaolin, copper, chalcedony, agate, jasper, hydraulic and lithographic limestones are known to exist in Missouri, but the extent of their occurrence the explorations of geologists have not yet fully ascertained. Future researches will determine the limits and economic value of these resources. But ochres, cobalt, nickel, marble, flag and mill stones, barytes, glass-sand, granite, fire-clay, zinc, iron, lead, and coal are found in abundance.

The most useful of these minerals occur in quantities that are seemingly unlimited. Our stores of saccharoidal sand, clays, granite, zinc, lead, coal, and iron are sufficient to satisfy for hundreds of years the wants of a large population.

The area of the coal fields of Missouri is more than 26,000 square miles.

Our Iron ores, too abundant to be confined in the depths of earth, were upheared into positions of easier accessibility. In the architecture of Missouri, not only was a part of the foundations, but also of the superstructure, built of 
ironstone. The massive masonry of several of our mountains is constructed of this material. Centuries of consumption will not exhanst our supplies of iron ore.

Missouri is well adapted to manufactures. Its fields and mines yield the raw material for a great varlety of industrial products. In the mountainous portions of the state, there is an abundance of water-power. The mills and workshops whose motive force is steam can be located to suit the needs of manufacturers. Well arranged lines of railway intersect the state and afford convenient facilities for the interchanges of commerce. Low taxes, moderate rates of transportation, nearness to patrons, and cheap supplies of land, food, labor, fuel, and raw material are the industrial advantages which Missouri presents to eastern merchants and manufacturers.

St. Louis is at once the commercial capital of Missouri and the central metropolis of the Mississippi valley. Its situation is high, healthful, and picturesque. The growth of the city is steady and rapid. Its annual increase in population is abont 12,000 . Wealth is now erecting elegant residences and stately warehouses. The dimensions of a grocery store which is now going up will indicate the magnitude of some of our new mercartile palaces. The building is 400 by 215 feet. It will be seven stories in height. A switch, running through the center of the structure and connecting with our main lines of railroad, will afford facilities for an easy and rapid transfer of goods. By its side, another warehouse of the same size is to be erected as soon as the completion of the first permits a removal of commodities from the stores which are to be dismantled to furnish a site for the second building. For the last five years, the annual average of new structures in St. Louis has been more than 2500. In the municipal permits, the appraised cost of the new buildings erected in St. Louis in 1889 was more than $\$ 9,600,000$; but their real value is at least $\$ 12,000,000$. In 1880 , the taxable property of the city was, in round numbers, $\$ 160,000,000$; in 1889 , it was $\$ 230,000,000$.

To illustrate the manufacturing greatness of St. Louis, only a few representative facts can be presented.

There are more than thirty shoe factories in the city. The productive capacity of the largest is 5000 pairs of shoes a day. There are six firms, each of which sells about $\$ 1,000,000$ worth of shoes a year. The annual sales of the largest shoe house amount to more than $\$ 3,000,000$. There is no city in the Mississippi valley which makes, within its corporate limits, as many boots and shoes as St. Louis does.

Besides smaller establishments, there are three great stove factories in the city. The capital of the largest is $\$ 1,000,000$. The works cover four acres. The number of workmen is about 500. Their wages average $\$ 1000$ a day. 6000 tons 
of iron are aunually manufactured into 40,000 stoves, whose aggregate value is about $\$ 600,000$. There are only three larger stove factories in the United States, and but one of these is west of the Alleghanies.

One of our iron companies, whose chief specialty is the manufacture of gas and water pipc, employs in its business a capital of $\$ 1,250,000$. It has on its pay roll an average of 750 men. Their wages amount to an annual aggregate of about $\$ 425,000$. The yearly consumption of material is about 1250 tons of wrought iron and 60,000 tons of cast iron. The approximate value of the annual product is $\$ 1500,000$.

Our largest range company has a capital of $\$ 500,000$. The cost of its equipment is $\$ 250,000$. The wages of its 300 workmen amount to $\$ 3300$ a weck. The number of artisans would be much larger if the company made its own castings. But the work of the factory is mostly confined to the assemblage of ready-made supplies. For malleable iron, steel, enameled ware, copper, nickel-plating, rivets, asbestos, and sundries, the company pays $\$ 44,000$ a month. The total ontlay for apparently inexpensive articles is sometimes surprisingly large. The rivets alone which this factory uses cost $\$ 2000$ a month. The value of the 30,000 ranges annually manufactured by this company is $\$ 2,000,000$. The foundations of a new warehouse have already been laid. This addition will enlarge the dimensions of the works to 378 by 138 feet.

The capital of one of our tobacco companies is $\$ 600,000$. The number of hands employed in its factory is 1500 . In 1889 , the company sold $22,000,000$ pounds of tobacco.

The largest brewery in the world is situated in St. Louis. It would by itself form a village. Its buildings and yards occupy forty-five blocks. The wagres of its 2000 workmen are $\$ 3000$ a day. The capital of the company is $\$ 5,000,000$. In 1889 , the product of this brewery was $25,000,000$ gallons of beer, worth $\$ 4,000,000$.

The new water-works, now under constrction, will cost $\$ 3,000,000$, and will supply the city with more than $100,000,000$ gallous of water a day.

The new bridge across the Mississippi, with its approaches and terminal railway, will involve a total expenditure of more than $\$ 6,000,000$. In less than two months it will be ready for use.

The present terminals and projected improvements of the old bridge require an outlay of $\$ 7,000,000$, of which $\$ 2,000,000$ are to be spent in the erection of a grand central station.

In the early days, the streets of St. Louis were covered with broken iimestoue. But teu years ago, the city began to use a better material. Our main 
avenues are now laid with granite. St. Louis has now 42 miles of as good pavement as there is in the world. The expense of this reconstruction is more than $\$ 3,600,000$. The work of opening and relaying streets now costs the city about $\$ 1,000,000$ a year.

The outlays for municipal improvements, recently finished, now going on, or soon to be undertaken, exceed $\$ 40,000,000$. The preceding figures illustrate the present industrial progress of St. Louis. The coming years will witness a still grander development. The impulse of enterprise and public spirit assures the future greatness of our metropolis.

St. Louis eujoys matchless advantages of situation. Its location in the heart of the continent and its vast system of river and rail communications invest the city with pre-eminent facilities for the interchanges of trade. Commercial prosperity is the happy necessity of its central position. More than a score of main lines of railroad radiate from this center to the circumference of the country, and the combined length of its navigable rivers would stretch three-quarters of the distance around the globe. The mercantile importance of so grand a system. of transportation can scarcely be exaggerated. "Every winter the waterways of the north are closed for months by ice. The Mississippi from St. Louis to the Gulf is generally open the year round. An interruption of navigation by an ice blockade is an infrequent event. When northern streans are frozen, the railroads, unrestrained by competition, commonly raise their freights. At St. Louis, the rivalry of an unobstructed river reduces the rates of railway transportation. The value of such commercial advantages, merchants and manufacturers will not fail to recognize. St. Louis has a powerful equipment of facilities for water carriage. Scveral lines of steamers are reinforced by an efficient flotilla of small boats. The Mississippi River Transportation Company has a fleet of eleven steam tugs and ninety barges. Their freight is chiefly cereals. Their capacity is 50,000 bushels each. But a full load requires nine feet of water. Sometimes the water is so low that the barges can carry ouly 20,000 bushels apiece. In this case, the cost of transportation is more than doubled. A depth of nine fect during the season of low water would effect a saving of two cents on every bushei of coln the cost of whose carriage to market river rates control. When it is recollected that the corn crop of the United States now exceeds $2,000,000,000$ bushels, and that the great bulk of this harvest is produced in the Mississippi valley, the full significance of this economy will be appreciated. Such facts demonstrate the national importance of deepening the channel of the Mississippi. The largest tugs of the St. Louis Transportation Company can tow 10,000 tons of freight. The movement by rail of so large a mass would require thirteen trains of forty cars each. Writh a good 
stage of water, a fleet of barges can make the trip from St. Louis to New Orleans in seren days. The distance by river is 1241 miles. A freight train, with its incident delays, would scarcely surpass this speed.

The unification of the American people by education, travel, inventive art, and the exchanges of trade, gives to natural advantages a steadily increasing share of their rightful supremacy in commerce and manufactures. The central situation of St. Louis and its superior facilities for transportation by river and rail cannot fail to attract the attention of northern enterprise. The city has now but half a million inhabitants. Before the lapse of many years its population will number a million. The certain growth of the city will constantly increase the value of all its properties. Men of means, sagaciously watchful of their own interests and recognizing the inevitable westward movement of accumulated wealth, should hasten to avail themselves of the proffered opportunities of lucrative investment. Northern merchants, manufacturers, and capitalists are cordially invited to a participation in the achievement of that commercial and industrial greatness which is the assured destiny of St. Louis. 


\section{The Metropolitan Attractions of St. Louis.*}

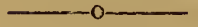

In all the centuries of human history, no geographical event has exerted so great an influence on the destinies of mankind as the discovery of America. The progress of the United States is the astonishment of the world. In less than three hundred years from the date of the first permanent settlement on our shores, a small colony has grown into a populatiou of $60,000,000$, and a narrow frontier upon the Atlantic has expanded into a public domain of more than $3,250,000$ square miles. In this brief period, our country has outstripped in material development all the older civilizations of the world. The great Republic is now the richest nation on the face of the globe. Political economy recognizes the unrestricted consecration of natural talents to special pursuits as one of the most productive factors of national wealth. No barriers of caste restrain the free exercise of American genius. Prosperous commonwealths, rich with the products of diversified industry, equipped with all the conveniences of modern invention, enlightened by the discipline of universal education, and instinct with the energies of civil freedom, now occupy the vast territory which three centuries ago was a continental wildermess. The prosperity of our Republic under a free government has increased the welfare of mankind. Ampler liberties and happier conditions of social life attest the foreign influence of our great example.

The United States will fitly commemorate the 400th anniversary of the discovery of America by an exposition of our national progress. A World's Fair will illustrate American advancement in art, science, and industrial skill. The location of the exhibition will depend upon the action of our National Legislature. St. Louis confidently invites members of Congress to a consideration of its superior advantages as a site for the World's Fair.

St. Louis has a population of about 500,000. The municipal limits include 40,000 acres. The length of the city is 19 miles. Its highest grounds are more than 200 feet above the average low water of the Mississippi, and more than 400

- The following address was written at the request and published by the anthority of the St. Lonis Congressional Commiltee on the World's Fair. It is reproduced because it presents fact which supp.ement the industrial stalistice of the preceding article. 
feet above the level of the ocean. The total length of its improved strcets is inore than 500 miles, and no city in the world has a better pavement than the granite blocks with which the central avemues of St. Louis are laid. Seventeen parks, with an aggregate extent of more than 2000 acres, afford opportunities for healthful recreation. Tower Grove Park contains 276 acres, and Forest Park 1370 acres. The former is laid out with exquisite taste and the latter is beautiful with all the wild charms of unreclaimed nature, and both, embellished with statues, pavilions, and fountains, are delightful pleasure-grounds. Shaw's Garden, with its rare wealth of flowers, and the Fair Grounds, with their interesting collection of wild animals, are also attractive places of popular resort. Street railroads are so numerous that every part of the city is easily accessible. The streets of St. Louis will be soon lighted by electricity. The fine architecture of stores, chnrches, and private residences adds to the attractiveness of the city. Our large hotels and spacious theaters afford ample accommodations for the entertainment of visitors.

The unimpeachable records of vital statistics prove that St. Louis is one of the healthiest cities in the world. Its nndulating surface and elevation above the Mississippi permit a perfect system of drainage. An inexhaustible supply of wholesome water promotes the health, cleanliness, and safety of the city.

The World's Fair will open on the first of May and close on the last day of October. During four of these months, the weather in St. Louis is delightful. The genial milduess of May, June, September, and October are almost the realization of an ideal climate. For the last four years, the temperature in July and August has been as comfortable as that of New York. Of the agreeable clemency of three of these seasons, experience enables me to speak with the certainty of personal knowledge. The tables of the Weather Service show that the fourth season was as mild as the other three. But the midsummer heat of St. Louis is sometimes oppressive. Still a comparison of the Health leports of the two cities shows that for a long series of years the percentages of cases of prostration by heat in New York and St. Louis are almost exactly the same. The atmosphere which encompasses cities on the seaboard, or on the. shores of the great lakes, is apt to be more fully charged with humidity than tie air which surrounds places remote from large bodies of water. But the presence of heated vapor is a climatic condition unfavorable to comfort or health. St. Louis is as free from this source of languor and debility as some cities in higher latitudes. But the occurrence of an exceptionally hot summer in 1892 is an incident of little moment. 'The people from northcru climes need not come to St. Louis in July and August. Assuredly, four months of fine weather are ampli tiuie 
for them to attend the Exposition, while visitors from the southern states and irom tropic lands will find the intensest heat of St. Louis less sultry than their own climates.

The vast majority of those who will throng the halls of the great Exposition will be persons of moderate means to whom economy will not be a matter of indifference. St. Louis is the central market of one of the largest and most productiye valleys in the world. The excellence and variety of its meats, grains, vegetables, and fruits cannot be surpassed. Its plenteous supplies of cheap food reduce the cost of living to the lowest limits.

St. Louis has been trained to habits of public hospitality. For more than thirty years the St. Lonis Fair, held in the suburbs of the city, has been the largest agricultural exhibition in the United States. Myriads of visitors throng its avenues and pavilions. The Fair lasts a week. One day this year, the attendance was over 143,000 persons. The spacious grounds, 143 acres in extent, are none too ample for the accommodation of so large a multitude. Our Exposition Building, situated in the heart of the city, covers two entire blocks and the intervening space of a wide street. The exhibition continues six weeks. The great hall seats 5000 people; but, from the opening to the close, the galleries and concert-room are crowded with visitors.

The autumnal festivities of St. Louis are brilliant. In 1878, it was my good fortune to witness the reception of the Shah of Persia at Paris. It was a gorgeously impressive pageant. The first evening after his arrival, all the central portions of the beautiful capital were ablaze with myriads of gas-jets. The scenic illuminations of St. Louis, though far less extensive than that of Paris, surpass in concentrated splendor the more diffused magnificence of the French display. These various attractions draw to St. Louis hundreds of thousands of guests. The easy accommodation of these vast throngs shows that our city has a capacity for entertainment equai to any demands which the World's Fair may make upon its hospitality.

It is probable that more than three-quarters of the visitors of the Exposition would be our own countrymen. Though the Fair will be open to the competition of every land, its pre-eminent purpose will be a display of the products of American genius and industry; consequently the convenience of our own people should be the decisive consideration in the selection of a site for the World's Fair. It is obvious that, with equal facilities for cheap and rapid transit, the center of a country is more accessible to the masses of its inhabitants than any point upon its distant circumference.

If circles one thousand miles in diameter be drawn around the centers of 
New York, Chicago, and St. Louis, it will be found that there were, in round numbers, in the

New York circle 20,100,000 inhabitants in 1880, and $3 t, 370$ miles of railroad in 1888.

$\begin{array}{llllllll}\text { Chicago " " } & 21,798,000 & \text { " } & 54,800 & \text { " } & \text { " } \\ \text { St. Louis " } & 23,838,000 & \text { " } & \text { " } & 77,570 \text { " }\end{array}$

Doubtless the census of 1890 will exhibit a still greater superiority of St. Louis to Its rivals. Our metropolis includes within a compass of flve hundred miles the capitals of fifteen commonwealths, over one-third of the population, and more than one-half of the wealth of the United States.

No city on the continent has as good facilities for 1nternal transportation as St. Louis. The Father of Waters and his thirty tributaries penetrate erery section of the Mississippi valley. No other central emporium in the world enjoys the advantage of 18,000 miles of river navigation. A vast system of water carriage would ensure the cheap and easy transportation of leavy exhibits. The fine steamboats which ply on the Mississippi and its affluents reduce the cost of travel and freightage.

Twenty-flve main lines of railroad converge at this terminal center. The arrival and departure of 392 trains a day indicate the vastness and activity of the railway communications of St. Louis. A city which is not only the center of our national territory, production, and population, but also of the railroad and river systems of the continent, seems justly entitled to preference as the site of the World's Fair. The number of suitable localities which the high and beautiful suburbs of St. Louis present will embarrass the duty of selection.

As an Exposition in the east celebrated the centennial birth-year of American Independence, it is but right that a World's Fair in the west should commemorate the 400 th anuiversary of the discovery of the westeru continent. There is an historic propriety in holding the Exposition in the great valley which De Soto explored, and in the city so long governed by countrymen of Columbus. There is no more flting spot for the celebration of an achievement whtch has invested the name of the navigator with imperishable renown than the great metropolis which in its huinble village days, was an integral part of the Spanish Empire.

Most of the foreign visitors to our Centennial Exposition limited their travels in this country to short excursions in the Atlantic states. Of the vast folio of American development, they read only a few marginal notes. They returned to their homes with no just conceptions of the extent and grandeur of the Great Republic. But those who come from other countries to attend a World's Fair in St. Louis will have larger opportunities to study the social and industrial 
condition of the American people. The length of their inland journey will compel foreign tourists to take broad views of the growth and resources of the United States. They will carry back to their own lands impressions of the magnitude and power of the American Union, and of the prosperity and happiness of its citizeus under the institutions of a free government, that will tend to preserve international peace and enlarge the civic rights of their countrymen.

- The proposed Exposition should be worthy of American greatness. It should be a commemoration of historic and matchless grandeur. In its halls should be exhibited the finest specimens of our agricultural and mineral wealth, the infinitely varied products of industrial handcraft, the exquisite masterpieces of artistic and inventive genius, and the countless material creations of that alert intelligence and restless enterprise and of those moral and civil forces that have caused the prosperity and greatness of our American civilization.

To insure the success of a World's Fair held upon its own grounds, St. Louis will exert all its energies. Its citizens have already raised a guarantee fund of $\$ 5,000,000$. The subscriptions are obligations that can be enforced at law. Its public-spirited capitalists are even willing to increase their princely contributious. In this tournament of knightly rivals, the gallantry of St. Louis is chivalric. It is hoped that the bravery which deserves will also win the Fair. A just appreciation of valid claims would assuredly awari the honor to our metropolis.

That the Legislature of the United States will select St. Louis as the site of the Exposition of 1892 is the earnest wish of one whose love for his adopted city seeks a national recognition of its merits.

\section{S. WATERHOUSE.}

\section{WASHINGTON UNIVERSITY,}

St. Louis, Mo. 


$$
\text { . }
$$ 

Gaylord PAMPHLET BINDER

Syracuse, N. Y.

Stackton, Calif. 
